\section{A VERSATILE PUBLIC OPINION SPEAKS ABOUT A MOBILE COAST LINE : A CASE STUDY IN BRITTANY, WESTERN FRANGE.}

\section{Herve Regnauld And Soazig Pian}

Université Européenne de Bretagne, Rennes 2

Laboratory Costel UMR 6554 CNRS, Place H. Le Moal 35043 Rennes, France

herve.regnauld@uhb.fr ; soazig.pian@uhb.fr

\section{Abstract:}

The coastal landscape of France is highly mobile, especially where the tidal range exceeds ten meters, like in Northern Brittany, on the English Channel. This mobility is strongly enhanced by storms, some of them having been exceptional during the last decades. The reaction of the local authorities to these storms is also highly variable. Some are getting used to cope with the changing coastline and do not make a great point of having such a mobile feature managed. Others react differently, and declare that storms are dangerous and create new risks along the coastline. The reason behind this difference is a political one. Some local communities use the storm in order to build an image of their coastline. They describe their coasts as vulnerable because they want to refuse the use of new equipment, or new industrial activity.

In France the coastline is defined by a law (dating back to 1986) and building within a hundred of meters of the coast is strictly limited. The French policy is to avoid any new building within this $100 \mathrm{~m}$ zone because the coast is known to be mobile, with changing features which provide no solid grounds for buildings. At the same time, most of the coastline is used for tourism and beaches (either sandy or gravelly) are considered as local resources for many local communities (communes, which are the smallest governing body in France). In the French tourist culture a large beach is a better resource than a small gravel flat one. These two points of view form a paradox. While local communities mostly accept the idea that the coast line may change, they do not accept that a beach is depleteable by it very nature. This means that some morphological changes are thought of as natural processes while others are seen as simply natural catastrophes. We argue that this is a cultural issue, not related to actual morphological behaviour. In order to make our point clear, we shall first describe how storms most often bring sediment to the coast and how they should be considered mainly as building the coast, not as destroying it (though this also sometimes happens). Our second point will deal with the local communities who use damages created by storms as political tools in their fight against a coastal management plan they do not want

\section{STORMS MAY ERODE THE GOAST BUT THEY ALSO BRING SEDIMENT TO THE BOAST}

Most of the storms that hit Brittany (figure 1) are linked to low pressure systems coming from the West. Average storm-waves in Ouessant are 5 to $6 \mathrm{~m}$ high. When they reach the region of Saint Malo they are reduced to about 2 to 3 metres. The entire coastline is in relative equilibrium with these storms and is perfectly able to withstand them. It may be said to be a storm-controlled coastal environment

Though, statistically speaking, exceptional storms do occur every 7 years, during the last decades their frequency has been increasing. The last of these exceptional storms have taken place in 1987, 1992, 1999, 2008 and in 2009 Wave height may reach 15 meters off Ouessant and 5 meters in Saint Malo (in 2008). Wind speed may reach $160 \mathrm{~km} / \mathrm{h}$ (in 2009). The effects on the coast line are significant. Soft sediment cliffs may retreat by more than one meter in one day [1]. Sand accumulations are usually breached and floods do invade back barriers marshes. Heavy rock boulders may be moved as far as ten meters in land [2]... Coastal landscape is clearly transformed by the storm 


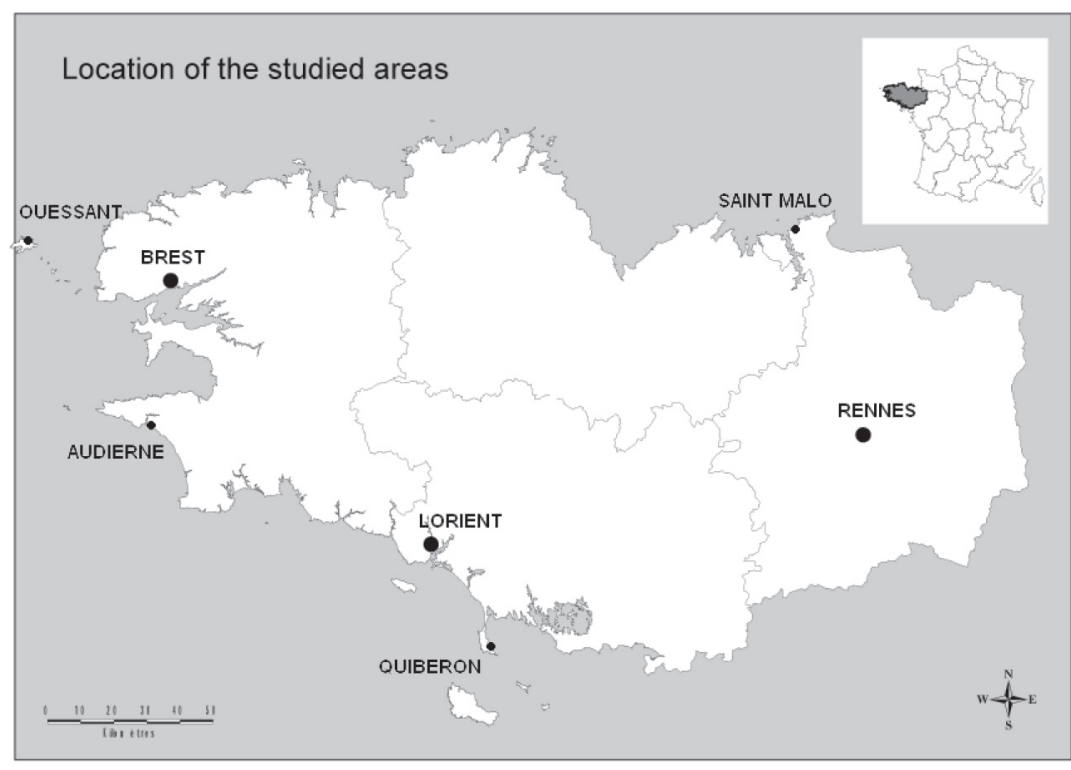

Figure 1 : Location of the main sites

Figure 2 shows the effects of the 1998 storm on the coastline close to Saint Malo. The fore dune was being protected by a fence system and some geotextile had been used to stabilize the sand on which Ammophila arenaria had been planted.

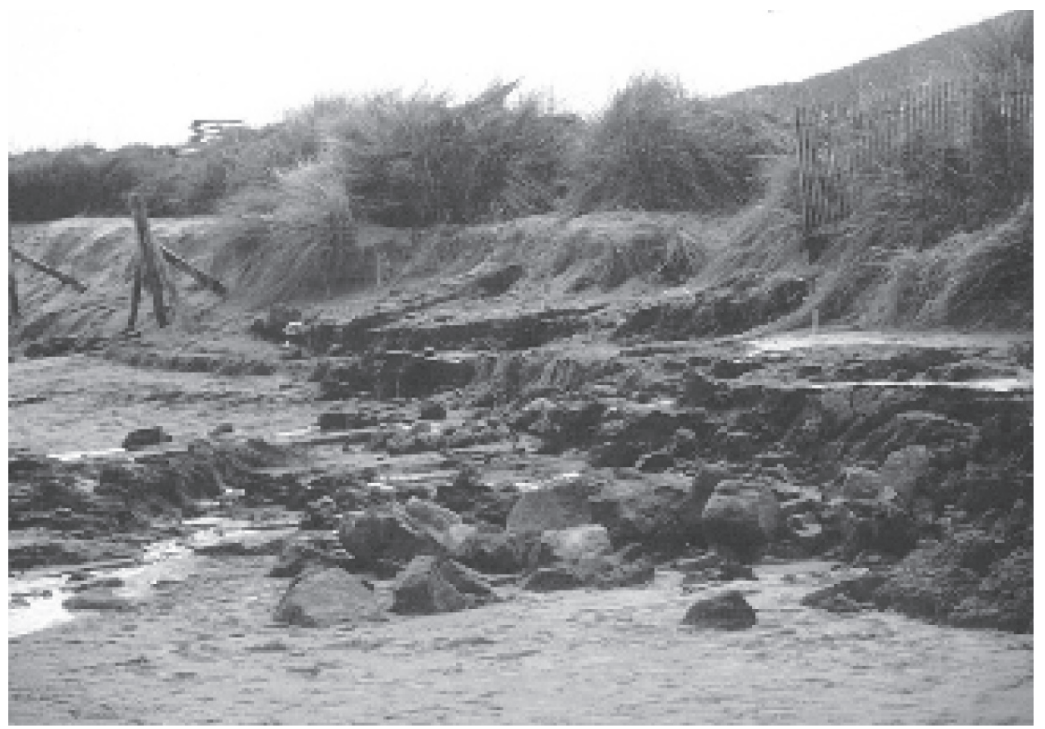

Figure 2 : Impact of the March 1998 storm on an archeological coastal site close to Saint Malo.

The storm destroyed the entire system and dune management works had to resume. The cost (at this moment) was about 300 French francs (about 45 Euros) par linear meter of coastline. Very close to this dune a cliff cut into soft material (coluvium and inherited glacial drifts) had receded by more than one meter. A detailed survey showed that most of the eroded sediment from the cliff had been moved to the sub tidal zone, at about 2 to 4 metres below the low tide level. Some of the eroded dune sediment was actually stored within the tidal zone
. During the following months, ordinary wave conditions and storms (none of which was particularly exceptional) moved this sand to the upper beach and to the dune toe. Ordinary winds had blown it back into the main dune system In 1999 the dune system had recovered its former profile and the resilience lag has been calculated to be about 9 months. The total amount of sediment was larger than before because the material which was previously stored in the cliff had been made available for the dune [3]. The geomorphological effects of the storm had 
been to transfer material from the receding cliff to the protruding dune. This mechanism is typical of storms. They move sediment and contribute to the building of barriers and/or dune fields inside of bays. Of course they do erode most of the capes, headlands or local cliffs.

On the Northern coast of Brittany, along the Channel, the tidal range may reach 13 meters, and the landscape varies a lot with the tides. Most of the local communities, who are in charge of managing the coast, are aware of the action of storms. On this coast beaches are, very often, pocket beaches and they display a high morphological variability. Neighbouring cliffs often show high rates of retreat. Their eroded material is quickly recycled within a short distance. Sedimentary cells are small and their behaviour is, most often, obvious. Local coastal managers are aware of their behaviour. When the coast is comprised of cliffs, along many isolated parts of the coastline the landscape is devoid of any buildings and is considered natural, even if it is not anymore because of introduced species. These types of sites are most often hard rock high cliffs with rocky platforms offshore and skerries. Sediment accumulations are scarce and have high variable morphology, but in situ outcrop they provide visitors with fixed visual beacons and help to build the idea that the landscape has some sort of permanence. Therefore the Northern coast is considered a mobile one, where cliffs retreat has low variability and beach behaviour has high variable behaviour. In that context, storms do accelerate sediment exchange across sedimentary cells and produce expected changes in the coastal landscape. the mobility of the landscape is not such an important political issue as it has been made to be for a long time inside political circles local coastline cultural representations.

The Southern coast of Brittany is very different and faces the Atlantic Ocean. The tidal range is lower (about 4 meters) and the wave regime is much more powerful. There are large extends of dunes with few buildings. In baie d'Audierne the dune system is about $20 \mathrm{~km}$ long. In Morbihan it is about $35 \mathrm{~km}$ long. These dunes are South
West facing the dominant wind/waves coming from the West. These dune fields are set along a beach which, from a sedimentary point of view, is a transit site; neither a source, nor a sink. The sand supply is, therefore, highly irregular and the windblown sand is delivered to the dune in a very irregular way. The down drift part of the coast has a positive sedimentary budget, but many local erosive pockets do exist (and most of them are linked with over frequentation). This part of the coast is seen as an endangered place. The source sites are small, the sink sites are small also and the transit sites, with their specific high morphological variability are very long. These sites do not belong to the same city and are not always managed by one a single organisation. Therefore, at a local scale every tiny movement of the dune toe is used by various people as an argument for endless discussions about coastal management. While an important issue such as sand mining offshore is at stake, these talks converge into an organised discourse .

\section{LOCAL GOMMUNITIES MAY USE THE CONGEPT OF EROSION IN ORDER TO FIGHT AGAINST LOCAL MANAGEMENT PLANS.}

In certain occasions various communities, organisations, associations and social groups may feel the need to reunite themselves into a wider group called a "collectif". Most often, this is due to the fact that they have a need to present a wide opposition to a political project they do not wish to accept. From 2005 to 2006, a project for sand mining off shore in Southern Brittany has been studied by a powerful international group (comprising French and Italian companies such as Lafarge and Italcementi). The sand should be mined 5 to 7 miles away at depth of about 35 meters. The sand would be used to make concrete and to build roads, houses and structures in Brittany. Today, Brittany has to import sand from neighbouring regions, which is likely to increase as many sand quarries are going to be closed. There is no alluvial sand anymore. Shifting to marine sand is a solution which has been chosen by the 
neighbouring regions and many companies have a lot of expertise in that field.

In Southern Brittany the situation is shown on figure 3. The coastal dune system extends from Port Louis to Quiberon. The source site is Port Louis, close to Lorient, which is an artificial tombolo build by the French navy during the $17^{\text {th }}$ century [4]

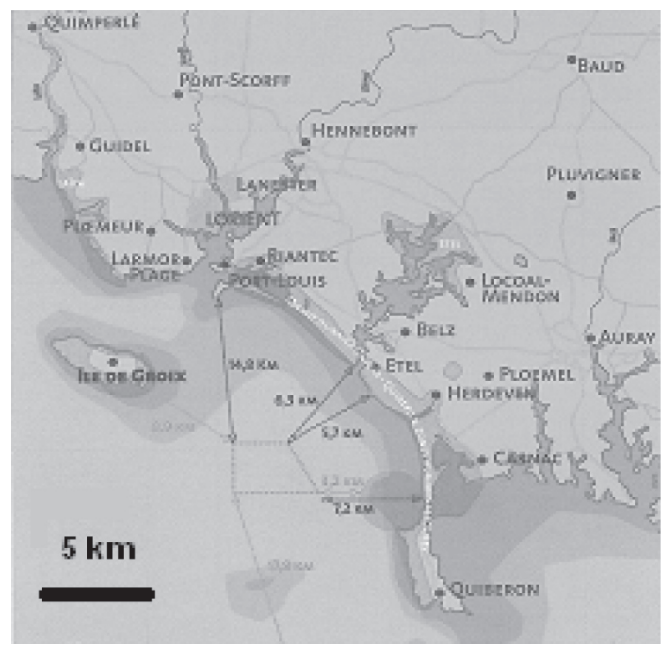

Figure 3: Location of the planned mining site and of the coastal sedimentary cell from Port Louis to Quiberon.

The sink site is the West facing barrier of the isthmus of Quiberon. The transit site bypasses the estuary of Etel. The main scientific question is to know if the coastal sands come from the projected mining site or belong to a disconnected stock. At first sight, there is no sign of link between the mining area and the coastal zone. In the mining area the sand is covered by a thin layer of silts which is only disturbed by worms' burrows. The sand are fossil sands dating back to a low sea level. They are alluvial sands of the palaeo river of Etel. Today they are fossilised. The mining companies have mapped the sea floor, and have run some wave model in order to simulate exceptional storms. The models show that there is no displacement of the sand to the coast. The coastal stock is clearly separated from the off shore stock.

Local population, united in a collectif "Le Peuple des Dunes" (i.e. the people of the dunes) strongly opposed the project. They decided they cannot trust mining companies and have asked for the help of experts. Researchers from two universities have run cruises at sea and studied the evolution of the coast line during the last 50 years (Arial photos [5]). Field work, sampling, laboratory analysis of the various sands has been done. Conclusions are the same as those of the mining companies : the two sand stocks have no relations. Moreover, shoreline retreat along the coastline is explained by the geomorphological behaviour of the system defined as a sedimentary cell [5] and is not related to offshore sediment movements (figure 4)

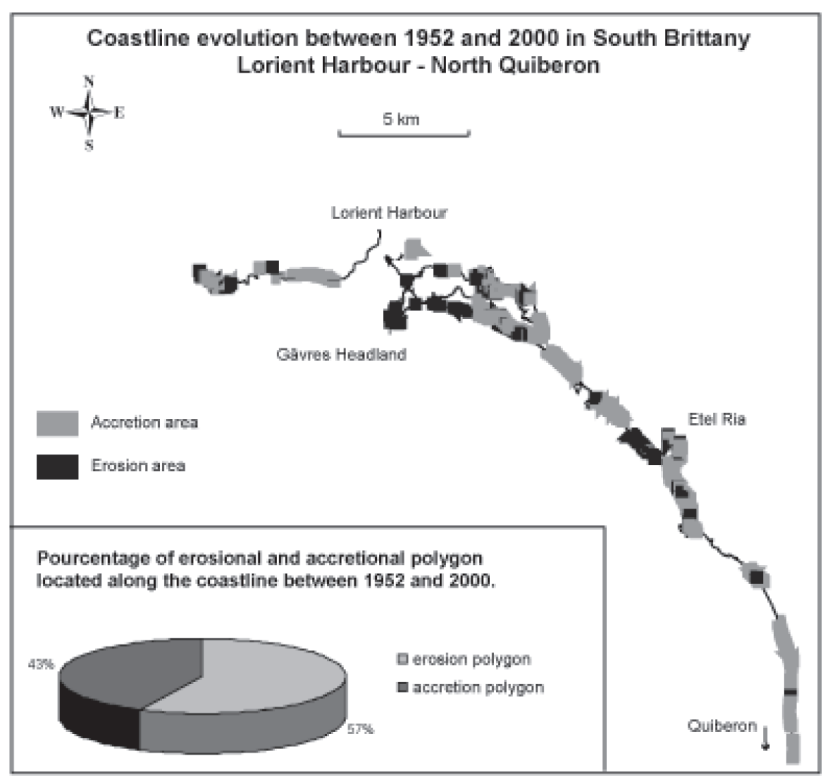

Figure 4 : behaviour of the sedimentary cell during the last 48 years, from air photos and field data.

'The Peuple des Dunes' has not accepted these results and has been using another strategy. They decided that scientists could not know the coastline because they do not live along the coast, but in two distant university towns. They said that the only efficient, truthful knowledge about the coast belongs to the local people. Local inhabitants claim they can build their own knowledge of the coast as opposed to the experts' scientific findings. They do not trust scientific methods and ask for more evidences. For example, they fear that the simulated storm models are not strong enough. With the increasing global change, they fear the next storm might be stronger than any previous ones [6]. They ask, therefore, for a stop of every mining plan before new, more solid, scientific data is gathered. 
DISCUSSION: MOBILITY OF LANDSCAPES, STORMS, REGIONAL IDENTITY AND SCIENCE : A DEAD END?

During the writing of this paper, the situation is at a stand still. An interesting question might actually be at play here other than what had been declared by the local communities. The use of the concept of mobile landscape seems to be an implicit means to assert territorial and cultural identity attachment. This may be explained by comparing the situation on the two coast lines of Brittany.

According to historical studies of the development of the coastal cities [4 and 7] the two coasts have many differences. On the Southern coast, Lorient has been founded by the central French power (i.e. the king) for the sake of the French Navy. From this new harbour, a large shipping company has been organising commerce with India and the French cities of the Indian Ocean. The name of the city "Lorient" means "the East". On the Northern coast Saint Malo is a very old city dating back to the Gauls (about $150 \mathrm{BC}$ ) and its economic growth is much more based on local funding and owe much less to the central power. This explains the simple fact that Saint Malo (during the $17^{\text {th }}$ and the $18^{\text {th }}$ centuries) was not depending too much on the French state for its growth and had developed good relations with Paris. Moreover, since the middle of the $19^{\text {th }}$ century the region of Saint Malo being directly linked with England, English tourists have come to France for many years. The local French population learned to live with new comers and to accept building facilities for large tourist activities. In this context, a storm is considered a natural occurrence that must be dealt with in such a manner that prevents interference with navigation, tourism and coastal buildings.

On the Southern coast, the relations between Lorient and the Paris government were very different. As a military base, Lorient was under strict control and could not develop large tourist activities. During the second half of the $20^{\text {th }}$ century, when the French state cut a lot of its navy activities, Lorient had to face severe difficulties and has not got all the financial help expected. This may explain why the local political organisation, (the Peuple des Dunes) has issued documents in which they try to promote a completely new type of ecological development, which would not rely on usual industrial activities. They have declared that new houses should be environmentally friendly and built out of wood, stones but not with concrete. In some public speeches some of them have even said that there are too many houses which are owned by outsiders (French people from other regions than Brittany), but this is not an official statement. Their real aim is not to understand the effect of storms on the sand stocks off shore, but to avoid any new building along the coast. The storm, and the mobility of the landscape is instrumentalised, used as a political trigger, which looks like an environmental issue, but which is aimed at winning a political sovereignty fight. This can be explained by the larger political context of France.

Inside of the continental French republic, all regions (22 all together) have exactly the same political status. The country has a centralised political system. Within the limits of continental France, two regions have a military movement fighting for independence (Basque Country and Corsica). In Brittany, there are some regionalist movements, one of them openly begging for a complete independence from France. Though there has not been any military action for the last 30 years and the regionalist movements are non violent in Brittany. In local elections they get about 5 to $10 \%$ of the votes.

The reaction of the local population to a coastal management plan must be understood in relation to this political context. According to French law, the land is managed by local bodies (collectivités territoriales), but the sea is under the control of the state (i.e. the Paris government). Jurisdictional limitations of the two authorities are, thus, defined by the high tide (+ surges) levels. What is below these levels belongs to the state, and what is above falls under the control of the locals. Building a large opposition to an offshore 
project is equivalent to building a large opposition to the state government itself, or to Paris. This is one ways of structuring a political cause. Namely: why would both the sea, and the sea-floor, belong to the state and not to local communities?

By contrast, in the Northern coast, there are no strong feelings of opposition against Paris. History has worked to build a reasonably friendly relation between Saint Malo and Paris. On the Southern coast of Lorient, however, relations have not always been so good. Locals use the storms' issue in order to establish that a true knowledge of the coast is only possible through people who actually observe the coast everyday; who live closer to it. This argument is designed to undermine any political authority, that is "far away", in Paris. The basic statement is: "local problems have to be solved by local people" and "scientists cannot understand a place in which they do not live". As scientists, we do not have any opinion about the first statement, but do not agree with the second. We cannot accept the idea that knowledge is place dependant. As a provisional conclusion, we can surmise that, in France today, the mobility of coastal landscape is not a scientific issue, but a widely opened political debate.

\section{Bibliography :}

1. Regnauld H., Lemasson L., Dubreuil V. The mobility of coastal landforms under climatic changes : issue for geomorphological and archeological conservation, in J.Hooke editor « Coastal Defence and Earth Sciences Conservation », Geological Society Publishing House, (1998)103-114.

2. Fichaut B., Suanez S. Les blocs cyclopéens de l'Ile de Banneg (archipel de Molène, Finisterre) : accumulation supratidales de haute énergie. Géomorphologie, Relief, Processus, Environnement, (2008) $1:$ 15-32.

3. Regnauld H.,Pirazoli P.A., Morvan G., Ruz M. Impacts of storms and evolution of the coastline. Marine Geology, vol 210, (2004) 1-4: 325-337.

4. Mézin L., Le Bouedec G., Haudrère P., Les compagnies des Indes, Editions Ouest France (1999) : 1 -324.

5. Pian S., Regnauld H., Menier D. Interactions nature/société et vulnérabilité du littoral : quelques exemples en Bretagne Sud. Actes du colloque international pluridisciplinaire «le littoral : subir, dire, agir » (2008) http:// WwW.ifresi.univ-lille1.fr/Littora12008/ Themes/Theme_4/Seance1/Pian.pdf

6. Pirazzoli P.A., Regnauld H., Lemasson L. Changes in storminess and surges in Western France during the last century. Marine.Geology., 210 (2004) : 307-323.

7. Lespagnol A., Messieurs de Saint Malo, une élite négociante au temps de Louis XIV. Presses Universitaires de Rennes (1996) : 1-334. 